Copyright (C) 2021 The Author/s

This work is licensed under a CC-BY 3.0 License

Peer review method: Double-Blind

Accepted: September 16, 2021

Published: November 23, 2021

Original scientific article

DOI: https://www.doi.org/10.47305/JLIA2137121kb

\title{
INFORMATION AND COMMUNICATIONS TECHNOLOGY AS A TOOL TO SUBSTITUTE IN-PERSON VISITS IN THE SERBIAN PRISON SYSTEM DURING THE COVID-19 RESTRICTIVE MEASURES
}

\author{
Milica Kolaković-Bojović \\ Institute of Criminological and Sociological Research - Belgrade, Serbia \\ ORCID iD: https://orcid.org/0000-0002-3130-5128 \\ kolakius@gmail.com
}

\begin{abstract}
In an attempt to properly address one of the greatest challenges for prison administrations around the world facing Covid-19, namely, to ensure regular communication between the inmates and their families, the Serbian Penal Administration, supported by German NGO Help e.V, procured the ICT equipment aimed at substituting the in-person visits. The author decided to assess the impact of this pilot project on the right of inmates to communicate with their family members, exploring their attitudes and the attitudes of professionals/prison staff that work with them, to get both perspectives. The results of the research showed that the online communication ensured through the pilot project has significantly contributed to preserving contacts and family relations in the changing environment of the Covid-19 restrictive measures, although it cannot completely replace family visits based on, in-person contact. However, the research also led to some of the remaining obstacles to a wider application of this, substitutive approach, among others, concerning the lack of IT literacy and the both of inmates and their family members, and to the life in poverty and/or in remote country areas. Additionally, this research identified a remaining need for further financial investment in the IT equipment to ensure adequate frequency and duration of communication, but also the need to revise/upgrade an existing treatment approach to integrating modern technologies/IT literacy as tools to contribute to the effectiveness of inmates' reintegration.
\end{abstract}

Keywords: Prison System; Covid-19, Inmate; Communication; New Technologies; Serbia

\section{INTRODUCTION}

The right of inmates to preserve contact with their family members plays an important role in preserving family relationships and significantly contributes to the efficient reintegration as a precondition for the reduction of recidivism. In addition to this, regular contacts have a positive impact on the psychological health and well-being of inmates. Prisoners shall be allowed under necessary supervision to communicate with their family and reputable friends at regular intervals, both by correspondence and by 
receiving visits. An untried prisoner shall be allowed to inform immediately his family of his detention and shall be given all reasonable facilities for communicating with his family and friends, and for receiving visits from them, subject only to restrictions and supervision as are necessary in the interests of the administration of justice and the security and good order of the institution (UN 1955, 92). This right was further developed in the field of child-friendly justice, where comprehensively recognized as an integral part of the right to fair and humane treatment and is essential to the preparation of juveniles for their return to society (UN 1990, 59). The UN Convention on the Rights of a Child (article 37(c)) underlines that a child shall have the right to maintain contact with his or her family through correspondence and visits, save in exceptional circumstances (UN 1989).

A unanimous validity of this right is also visible from the fact that even "disciplinary sanctions or restrictive measures shall not include the prohibition of family contact" (UN 2015, 43(3)). This means that family contact may only be restricted for a limited period and as strictly required for the maintenance of security and order. In addition to the disciplinary measures, an additional factor that frequently prevents exercising the right to contact with family and friends could be seen in the fact that the institutions that detain children are often poorly located geographically, making visits from families difficult - especially those of socio-economically disadvantaged backgrounds (Nowak 2019, 269).

\section{INMATE'S RIGHT TO COMMUNICATION IN THE COVID-19 ENVIRONMENT}

Since the first case of Covid-19 was reported in China at the end of 2019, all societal forces throughout the world have been mobilized to battle the pandemic. Many essential everyday activities were suspended including traveling, meeting in-person, and even leaving the place of living during the lock-down. In just a few weeks, millions of people around the world experienced some aspects of the deprivation of liberty, including the obligation of keeping physical distance and sometimes even separation from their families. In parallel, the regime applicable to inmates becomes more restrictive. For those families whose members either parents or children were incarcerated, the pandemic has brought cancelation of the already limited communication through the visits (Bateman 2020,4). Phone calls are often the main channel of communication between parents in prison and their children, and the restricted regimes made it more difficult for people in prison to gain access to phones (Minson 2021, 9). Both they and their families are likely to be anxious about the risk of the transmission of Covid-19 (HLPR 2020, 2). This continuous face with a fear of unknown danger, accompanied with the lack of information on the health condition of their loved ones and the disruptions in a routine because of Covid-19, can trigger depression and anxiety, but also get worse existing mental diseases conditions among 
juvenile justice population, that are often related to previous trauma (Barnert 2020, 2). All of this triggered the human rights treaty bodies and international organizations around the world to call upon decreasing the negative impacts of the pandemic on persons deprived of liberty. The UN High Commissioner for Human Rights Michelle Bachelet has said: "Imprisonment should be a measure of last resort, particularly during this crisis" (Bachelet 2020). The High Commissioner urged governments and relevant authorities to work quickly to reduce the number of people in detention and to examine ways to release those particularly vulnerable to Covid-19, but also continue to provide for the specific health-care requirements of women prisoners, including those who are pregnant, as well as those of inmates with disabilities and of juvenile detainees.

Considering this, where in-person visits are restricted or prohibited as part of contagion prevention efforts, it is essential that other means of maintaining contact be made easily and freely available for all families (ACPH 2020). This should include the provision of or extension of the use of free telephone and video calling, emailing and instant messaging, and free or subsidized postal contact (Halton 2020). For young inmates and children in correctional institutions, it is of special importance that contact of this kind is frequent and flexible, to minimize anxiety and distress for children. Cost should never be a barrier to a child's contact with their family (Halton 2020).

The urgent need to find alternative methods of communication has been immediately recognized by the expert community. However, it has been most poorly implemented in practice, due to a lack of resources that have been widely redirected to health protection, as a priority within the newly occurring circumstances. One of the exceptions, and an example of good practice in this regard, could be found in the pilot project implemented by the Serbian Penal Administration during the 2020 Covid-19 restrictive measures.

\section{RESPONSE TO THE COVID-19 RESTRICTIVE MEASURES IN THE SERBIAN PENAL SYSTEM}

Since the very first case of the Covid-19 infection was confirmed in Serbia on 6 March 2020, the major concern of the prison administration was to prevent the disease from further spreading among inmates and prison staff, but also to ensure isolation and proper medical treatment for those already infected. However, since the Serbian Government opted for a very restrictive regime, including the closing of schools, a lockdown, physical distancing, travel restrictions, etc. the inmates were facing a longterm prohibition of family visits, which significantly affected their right to communicate with the family members.

Recognizing the urgency of the situation, as a part of Help's project 'Support to Socio-Economic Stability in the Western Balkans 2019-2020' funded through German Development Cooperation, the prison administration decided to establish alternative 
mechanisms of communication, through the procurement of IT equipment. Some of the main criteria to implement this pilot project were the urgency to reestablish communication, mobility of the equipment, and the low price since there were no large resources available or enough time to plan and ensure additional budget. Therefore, with the support of the Help e.V. equipment worth 4,078.56 Euros, 16 tablets with a paid internet package of $20 \mathrm{~GB}$ per month for the next 24 months, was donated with the consent of the Administration, for use in nine institutions for the execution of penal sanctions, including the correctional institution for juveniles (Kolaković-Bojović and Batrićević 2021). The Information and Communications Technology (ICT) equipment was offered to inmates to maintain communication through the video calls with their family members, using the Viber application and therefore, free of charge. The frequency of calls varied depending of the correctional institution and the number of inmates, but the average was weekly.

\section{METHODOLOGY}

Research Phases and Sampling

The research which resulted in the results presented in this paper was conducted as a part of the comprehensive Impact Assessment of Re-socialisation program applied by NGO Help e.V. (Improvement of the treatment programs in correctional institutions for adults and juveniles - SOE03-19) ${ }^{1}$ in 2020. The Program included various activities aimed at supporting the treatment, reintegration, and post-penal care, through the workshops, training, and procurement of the equipment aimed at improving living conditions and the treatment in the correctional institutions, but also at gaining professional skills and increasing (self)employment opportunities for convicted persons (Kolaković-Bojović and Batrićević 2020).

The research timeframe was developed before the Covid-19 pandemic, covering May-October 2020. Faced with the Covid-19 travel restrictions, the research team decided to adjust the methodological framework in terms of the research methods to be applied, and therefore, all of the three stages (May-June, July-September, and September-October) of the research were finished within the restrictive Covid-19 environment:

\footnotetext{
${ }^{1}$ Help e.V. Program subjected to the assessment was implemented in the period initiatives relevant for the scope of this analysis, covering the period from September 2014 to November 2020, through the several stages: Poverty reduction and enhancement of employment opportunities of marginalized and vulnerable population groups in Serbia (Help e.V.: Project Nr.: SER 99-13) May 2013-December 2016; Support to micro businesses in Serbia, phase II (Help e.V. Project No.: SER 126) June 2016-December 2017; Support to the socio-economic stability in the Western Balkans 2017-2019 (Help e.V.: Project No.: SOE-01-17); Support to socio-economic stability in the western Balkans region 2019-2020 (Help e.V.: Project No.: SOE-03-19).
} 
Research Phase I: In this stage, the authors prepared a comprehensive, in-depth questionnaire for the beneficiaries and the prison staff to enable them to express their attitudes on the program comprehensively in writing and therefore to substitute in vivo interviews. The questionnaire was distributed in electronic form through email. ${ }^{2}$

Research Phase II: Based on the information gathered through the questionnaires, a set of additional questions for the phone call interviews was developed. After data collection and analysis experts gathered the last set of information through in-depth qualitative telephonic interviews with ex-prisoners who are beneficiaries of the selfemployment program support. Finally, experts conducted interviews with the representatives of the prison administration (hereafter: PA) and partner NGOs Help e.V.

Research Phase III: In this stage, all the information collected was analyzed and the conclusions and recommendations were defined based on the findings. ${ }^{3}$

As earlier explained, the Help Re-socialization Program implemented many activities aimed at support to the treatment, reintegration, and post-penal care. Therefore, the whole research included 265 individuals in total, where 252 persons were included through the questionnaires distributed via management of the correctional institutions, 7 persons (10\% of the total) are ex-prisoners / Help e.V. self-employment program beneficiaries, 2 persons from PA, 2 Help e.V. representatives and 2 NGO representatives.

The stratification of the sample and the selection of the participants were made in cooperation with the authors and the prison administration and the management of the 6 correctional institutions where the Program activities were implemented ${ }^{4}$ through the two subgroups: the subgroup of inmates and the subgroup of prison staff/professionals.

For the group of inmates, the focus was on the reflection of the structure of the prison population in total. For the group of professionals, an intention was to reflect upon the Help e.V. Program beneficiaries as much as possible. ${ }^{5}$

\footnotetext{
${ }^{2}$ To enable prison administration management to choose modalities of collecting and sharing findings with the members of the expert team (hard copy originals of the questionnaires were sent by mail, scanned originals sent by email or electronically filed questionnaires).

${ }^{3}$ For more info on the research steps undertaken within research phases, see: (Kolaković-Bojović and Batrićević 2020).

${ }^{4}$ Correctional Institution in Sremska Mitrovica, Correctional Institution in Niš, Correctional Institution for Women in Požarevac, Correctional-educational Institution for Juveniles in Kruševac, District Prison in Vranje and District Prison in Sombor.

${ }^{5}$ The role of the Help e.V. management in this regard was limited to providing data and contacts upon the Expert Team request, in order to ensure the integrity of the research process.
} 
Table 1: Status/Affiliation of Interviewed Persons (Source: Author's depiction)

\begin{tabular}{|l|c|c|c|}
\hline \multicolumn{1}{|c|}{ Institution } & Convicted Persons & Employees & Director \\
\hline $\begin{array}{l}\text { Correctional Institution in Sremska } \\
\text { Mitrovica }\end{array}$ & 20 & 13 & $/$ \\
\hline Correctional Institution in Niš & 113 & 7 & $/$ \\
\hline $\begin{array}{l}\text { Correctional Institution for Women in } \\
\text { Požarevac }\end{array}$ & 11 & 1 & 1 \\
\hline $\begin{array}{l}\text { Correctional-educational Institution for } \\
\text { Juveniles in Kruševac }\end{array}$ & 49 & 20 & 1 \\
\hline District Prison in Vranje & 3 & 5 & $/$ \\
\hline District Prison in Sombor & 5 & 3 & 2 \\
\hline TOTAL & 201 & 49 & \\
\hline
\end{tabular}

When it comes to the age structure of the sample, within the subgroup of inmates, the predominant group were inmates $21-40$ years old $(51.74 \%)$, followed by 18 21 years old group and 40-65 (18.9\%). This information plays an important role since the age of inmates significantly influences their online communication ability/preferences and their attitude regarding the usage of modern technologies, in general.

Table 2: Age of Interviewed Persons - Convicted Persons (Source: Author's depiction)

\begin{tabular}{|l|c|c|c|c|c|}
\hline \multicolumn{1}{|c|}{ Institution } & Under 18 & $\mathbf{1 8 - 2 1}$ & $\mathbf{2 1 - 4 0}$ & $\mathbf{4 0 - 6 5}$ & Over 65 \\
\hline Correctional Institution in Sremska Mitrovica & $/$ & 1 & 15 & 4 & $/$ \\
\hline Correctional Institution in Niš & 3 & 6 & 75 & 26 & 3 \\
\hline $\begin{array}{l}\text { Correctional Institution for Women in } \\
\text { Požarevac }\end{array}$ & $/$ & $/$ & 6 & 5 & $/$ \\
\hline $\begin{array}{l}\text { Correctional-educational Institution for } \\
\text { Juveniles in Kruševac }\end{array}$ & 11 & 35 & 3 & $/$ & $/$ \\
\hline District Prison in Vranje & $/$ & $/$ & 2 & 1 & $/$ \\
\hline District Prison in Sombor & $/$ & $/$ & 3 & 2 & $/$ \\
\hline TOTAL & 14 & $\mathbf{4 2}$ & 104 & 38 & 3 \\
\hline$\%$ & $6.96 \%$ & $20.89 \%$ & $51.74 \%$ & $18.9 \%$ & $1.49 \%$ \\
\hline
\end{tabular}

This information may seem less relevant for the subgroup of prison staff/professionals, but in fact, it is important for shaping their views on the procurement and use of ICT equipment, both in terms of their computer literacy, to accept novelties, and to support inmates to maintain this way of communication, especially those missing necessary skills. Considering this, most of the interviewed employees (65.31\%) were mid-age, while $32.65 \%$ were young or early mid-age. Only one interviewed employee (2.04\%) was over 65. 
Table 3: Age of Interviewed Persons - Employees (Source: Author's depiction)

\begin{tabular}{|l|c|c|c|c|c|}
\hline \multicolumn{1}{|c|}{ Institution } & Under 18 & $18-21$ & $21-40$ & $40-65$ & Over 65 \\
\hline $\begin{array}{l}\text { Correctional Institution in Sremska } \\
\text { Mitrovica }\end{array}$ & $/$ & $/$ & 8 & 5 & $/$ \\
\hline Correctional Institution in Niš & $/$ & $/$ & 1 & 5 & 1 \\
\hline $\begin{array}{l}\text { Correctional Institution for Women } \\
\text { in Požarevac }\end{array}$ & $/$ & $/$ & $/$ & 1 & $/$ \\
\hline $\begin{array}{l}\text { Correctional-educational Institution } \\
\text { for Juveniles in Kruševac }\end{array}$ & $/$ & $/$ & 4 & 17 & $/$ \\
\hline District Prison in Vranje & $/$ & $/$ & 2 & 3 & $/$ \\
\hline District Prison in Sombor & $/$ & $/$ & 1 & 2 & $/$ \\
\hline TOTAL & 0 & 0 & 16 & 32 & 1 \\
\hline$\%$ & $0 \%$ & $0 \%$ & $32.65 \%$ & $65.31 \%$ & $2.04 \%$ \\
\hline
\end{tabular}

In addition to the age of interviewed persons, for the first subgroup, important information was the duration of the imposed sanctions, considering the seriousness of the impact which long-term sanctions have on the knowledge and skills of inmates. One of the main fields where this impact goes to a significant extent is the ability to use modern technologies, considering their increasing importance for everyday life.

Taking this into account, it is important to mention that $30.92 \%$ of inmates were sentenced to $3-5$ years in prison, while $48.02 \%$ were sentenced to prison in duration over 5 years. This means that $79 \%$ of the interviewed inmates were serving long-lasting sentences.

Table 4: Imposed Sanction (Source: Author's depiction)

\begin{tabular}{|c|c|c|c|c|}
\hline Institution & Up to 1 year & $1-3$ years & 3-5 years & $\begin{array}{l}\text { More than } \\
5 \text { years }\end{array}$ \\
\hline Correctional Institution in Sremska Mitrovica & / & 2 & 8 & 10 \\
\hline Correctional Institution in Niš & 1 & 19 & 37 & 56 \\
\hline $\begin{array}{l}\text { Correctional Institution for Women in } \\
\text { Požarevac }\end{array}$ & / & 3 & 1 & 7 \\
\hline District Prison in Vranje & 3 & / & / & / \\
\hline District Prison in Sombor & / & 4 & 1 & / \\
\hline $\begin{array}{l}\text { Correctional-educational Institution for } \\
\text { Juveniles in Kruševac }\end{array}$ & \multicolumn{4}{|c|}{$\begin{array}{l}\text { * Since in the case of juveniles, educational measure - remand to the } \\
\text { educational-correctional institution is imposed, its initial duration is the } \\
\text { same. Namely, according to article } 21 \text { paragraph } 3 \text { of the Law on Juvenile } \\
\text { Criminal Offenders and Criminal Legal Protection of Juveniles (Official } \\
\text { Gazette of the Republic of Serbia, No. } 85 / 2005) \text {, a juvenile stays in an } \\
\text { educational-correctional institution for at least } 6 \text { months and at maximum } \\
4 \text { years, but the court is obliged to reconsider every } 6 \text { months whether } \\
\text { there are grounds to stop the enforcement of the educational measures or } \\
\text { to replace it with another educational measure. }\end{array}$} \\
\hline TOTAL & 4 & 28 & 47 & 73 \\
\hline$\%$ & $2.63 \%$ & $18.42 \%$ & $30.92 \%$ & $48.02 \%$ \\
\hline
\end{tabular}


When it comes to the gender structure of the sample, the male was predominant (93.53\%), which approximately reflects the gender structure of all wards in the institution. For the employees, the sample was not ideally balanced, but reflected the real gender structure of professionals in selected prisons, with $61.22 \%$ of male and $38.78 \%$ of female professionals interviewed.

Table 5: Gender of Interviewed Persons (Source: Author's depiction)

\begin{tabular}{|l|c|c|c|c|}
\hline \multirow{2}{*}{ Institution } & \multicolumn{2}{|c|}{ Convicted Persons } & \multicolumn{2}{c|}{ Employees } \\
\cline { 2 - 5 } & Male & Female & Male & Female \\
\hline $\begin{array}{l}\text { Correctional Institution in Sremska } \\
\text { Mitrovica }\end{array}$ & 20 & $/$ & 7 & 6 \\
\hline Correctional Institution in Niš & 113 & $/$ & 7 & $/$ \\
\hline $\begin{array}{l}\text { Correctional Institution for Women in } \\
\text { Požarevac }\end{array}$ & $/$ & 11 & $/$ & 1 \\
\hline $\begin{array}{l}\text { Correctional-educational Institution for } \\
\text { Juveniles in Kruševac }\end{array}$ & 47 & 2 & 10 & 10 \\
\hline District Prison in Vranje & 3 & $/$ & 3 & 2 \\
\hline District Prison in Sombor & 5 & $/$ & 3 & $/$ \\
\hline TOTAL & 188 & 13 & 30 & 19 \\
\hline$\%$ & $93.53 \%$ & $6.46 \%$ & $61.22 \%$ & $38.78 \%$ \\
\hline
\end{tabular}

For the same reason as for the age structure, the education level of the interviewed persons has been considered, as an important factor that has an impact on the expectations of inmates, it is also associated with the capacities to mastery the ICT skills and to accept novelties.

While, as expected, the employees were mostly highly educated, $40 \%$ of inmates have finished only primary school, while $46 \%$ of them have finished high school at the moment of conducting the research.

Table 6: Education Level of Interviewed Persons (Source: Author's depiction)

\begin{tabular}{|c|c|c|c|c|}
\hline Institution & $\begin{array}{l}\text { Without } \\
\text { Elementary } \\
\text { School }\end{array}$ & $\begin{array}{c}\text { Elementary } \\
\text { School }\end{array}$ & $\begin{array}{l}\text { High } \\
\text { School }\end{array}$ & $\begin{array}{c}\text { Secondary } \\
\text { School or } \\
\text { Faculty }\end{array}$ \\
\hline \multicolumn{5}{|c|}{ Education Level of Interviewed Persons - Convicted Persons } \\
\hline Correctional Institution in Sremska Mitrovica & 1 & 7 & 12 & / \\
\hline Correctional Institution in Niš & 4 & 36 & 63 & 10 \\
\hline Correctional Institution for Women in Požarevac & / & 2 & 6 & 2 \\
\hline $\begin{array}{l}\text { Correctional-educational Institution for Juveniles in } \\
\text { Kruševac }\end{array}$ & 10 & 32 & 6 & 1 \\
\hline District Prison in Vranje & / & 2 & 1 & / \\
\hline District PrisoninSombor & / & 1 & 4 & / \\
\hline TOTAL & 15 & 80 & 92 & 13 \\
\hline$\%$ & $6 \%$ & $40 \%$ & $46 \%$ & $6.5 \%$ \\
\hline
\end{tabular}




\begin{tabular}{|l|c|c|c|c|}
\hline \multicolumn{5}{|c|}{ Education Level of Interviewed Persons - Employees } \\
\hline Correctional Institution in Sremska Mitrovica & $/$ & $/$ & 7 & 6 \\
\hline Correctional Institution in Niš & $/$ & $/$ & 3 & 4 \\
\hline Correctional Institution for Women in Požarevac & $/$ & $/$ & $/$ & 1 \\
\hline $\begin{array}{l}\text { Correctional-educational Institution for Juveniles in } \\
\text { Kruševac }\end{array}$ & $/$ & $/$ & 6 & 14 \\
\hline District Prison in Vranje & $/$ & $/$ & 1 & 4 \\
\hline District Prison in Sombor & $/$ & $/$ & 1 & 2 \\
\hline TOTAL & $/$ & $/$ & 18 & 31 \\
\hline$\%$ & $0 \%$ & $0 \%$ & $36.73 \%$ & $63.27 \%$ \\
\hline
\end{tabular}

\section{FINDINGS}

The answers gathered from the interviewed persons showed that $68.16 \%$ of inmates directly took part in the Project activities, compared with $87.75 \%$ of employees.

Table 7: Participation of the Interviewed Persons in the Project Activities (Source: Author's depiction)

\begin{tabular}{|l|c|c|c|c|}
\hline \multicolumn{1}{|c|}{$\begin{array}{c}\text { Status/Affiliation of Interviewed } \\
\text { Persons }\end{array}$} & \multicolumn{2}{c|}{ Inmates } & \multicolumn{2}{c|}{ Employees } \\
\hline Participation in the Project activities & YES & NO & YES & NO \\
\hline $\begin{array}{l}\text { Correctional Institution in Sremska } \\
\text { Mitrovica }\end{array}$ & 18 & 2 & 13 & $/$ \\
\hline Correctional Institution in Niš & 93 & 20 & 7 & $/$ \\
\hline $\begin{array}{l}\text { Correctional Institution for Women in } \\
\text { Požarevac }\end{array}$ & 9 & 2 & 1 & $/$ \\
\hline $\begin{array}{l}\text { Correctional-educational Institution for } \\
\text { Juveniles in Kruševac }\end{array}$ & 13 & 35 & 14 & 6 \\
\hline District Prison in Vranje & 3 & $/$ & 5 & $/$ \\
\hline District Prison in Sombor & $/$ & $5^{*}$ & 3 & $/$ \\
\hline TOTAL & 137 & 64 & 43 & 6 \\
\hline$\%$ & $68.16 \%$ & $31.84 \%$ & $87.75 \%$ & $12.25 \%$ \\
\hline
\end{tabular}

When it comes to the attitudes of the interviewed persons on this supplementary method of communication with the family members, $52.56 \%$ of them evaluated this experience as 'excellent', while $25.64 \%$ said that this experience was good. This means that almost $80 \%$ of the interviewed inmates gave positive evaluations of this way of this substitution to in-person visits. At the same time, 19.23\% of inmates said that this experience was satisfactory. Only $2.56 \%$ evaluated it as unsatisfactory. 
Table 8: How the Interviewed Persons Evaluate the Program in Which They Participated - Inmates (Source: Author's depiction)

\begin{tabular}{|l|c|c|c|c|}
\hline \multicolumn{1}{|c|}{ Institution } & Excellent & Good & Satisfactory & Unsatisfactory \\
\hline $\begin{array}{l}\text { Correctional Institution in Sremska } \\
\text { Mitrovica }\end{array}$ & 13 & 3 & 4 & $/$ \\
\hline Correctional Institution in Niš & 48 & 27 & 16 & 2 \\
\hline $\begin{array}{l}\text { Correctional Institution for Women in } \\
\text { Požarevac }\end{array}$ & 8 & 3 & $/$ & $/$ \\
\hline $\begin{array}{l}\text { Correctional-educational Institution for } \\
\text { Juveniles in Kruševac }\end{array}$ & 10 & 5 & 7 & 2 \\
\hline District Prison in Vranje & 2 & 1 & $/$ & $/$ \\
\hline District Prison in Sombor & 1 & 1 & 3 & 4 \\
\hline TOTAL & 82 & 40 & 30 & $2.56 \%$ \\
\hline$\%$ & $52.56 \%$ & $25.64 \%$ & $19.23 \%$ & \\
\hline
\end{tabular}

This evaluation was a bit different among professionals working in prisons, where $39.53 \%$ of interviewed employees said that this innovation was excellent, while $46.51 \%$ evaluated it as 'good'. Therefore, the higher percentage of respondents in this subgroup gave a positive evaluation (86.04\%), but the distribution between 'excellent' and 'good' was different than in the subgroup of inmates.

Table 10: How the Interviewed Persons Evaluate the Program in Which They Participated - Employees (Source: Author's depiction)

\begin{tabular}{|l|c|c|c|c|}
\hline \multicolumn{1}{|c|}{ Institution } & Excellent & Good & Satisfactory & Unsatisfactory \\
\hline $\begin{array}{l}\text { Correctional Institution in Sremska } \\
\text { Mitrovica }\end{array}$ & 7 & 5 & 1 & $/$ \\
\hline Correctional Institution in Niš & 5 & 7 & $/$ & $/$ \\
\hline $\begin{array}{l}\text { Correctional Institution for Women in } \\
\text { Požarevac }\end{array}$ & $/$ & $/$ & $/$ & $/$ \\
\hline $\begin{array}{l}\text { Correctional-educational Institution for } \\
\text { Juveniles in Kruševac }\end{array}$ & $/$ & 4 & 1 & $/$ \\
\hline District Prison in Vranje & 2 & 2 & $/$ & $/$ \\
\hline District Prison in Sombor & 3 & $/$ & $/$ & 0 \\
\hline TOTAL & 17 & 20 & 3 & $0 \%$ \\
\hline$\%$ & $39.53 \%$ & $46.51 \%$ & $6.97 \%$ & \\
\hline
\end{tabular}

In addition to the general evaluation which included the four possible answers to the respondents (from unsatisfactory to excellent), they were encouraged to express their opinion and to provide the main reasons (not) to opt for this model of communication. Considering this, the inmates underlined several positive aspects of this substitute to in-person visits. As expected, they appreciated this opportunity to bridge the communication gap caused by the restrictive measures. Most of them underline how precious was for them, not only to hear but also to see their family members and to 
benefit from the emotions expressed nonverbally. A bit unexpected, but some of them (mostly juveniles) explained that they experienced positive emotions in the online 'contact' with the familiar persons and objects, like pets, homes, or gardens, or we're happy because their parents were in the position to 'visit' them without spending money. At the same time, the most frequently underlined negative side of this innovation was the insufficient frequency and the duration of calls (usually weekly). In addition to this, they argued that there is no reason to limit these calls to the use of Viber.

Finally, they frequently reported a lack of resources on the side of their family members to access the internet at all or to smartphones or similar devices. Considering this, most of them suggested procurement of additional devices, but also expanding the usage of the devices to increase ICT and other skills and knowledge. Some juveniles suggested being allowed to use the devices in the context of spare time (e.g. to play video games).

When it comes to the attitudes of the professionals, in addition to what has been identified by inmates, they emphasized the stimulative effect of this substitute to person-visits to inmates, especially for juveniles and youngsters, "since it facilitates a stronger emotional interaction between them and their family members and encourages them to express their emotion, which has a positive impact on their future behavior" (Kolaković-Bojović and Batrićević 2021).

Concerning the negative sides of this innovation, in addition to what has been said by inmates, the professionals underlined an issue of the access to this way of communication for family members who live in poverty and or in rural, remote areas, especially those who are illiterate. They also provided some practical recommendations, related to the procurement of some additional equipment to ensure protection and long-life of the devices, like tabled cases and tablet holders.

They reiterated the need to step up with the use of apps other than Viber, to enable, among others, the employees in the educational-correctional institution in Kruševac to communicate and work with juveniles' family members online/without additional travel costs or their absence from the workspace (Kolaković-Bojović and Batrićević 2021).

\section{DISCUSSION AND CONCLUSIONS}

As the research findings showed that there is unanimous support to the introduction of the alternative modalities of the communication between the inmates and their family members, obviously the focus should be on the reasons they might trigger the differences in evaluation of this pilot project as 'excellent' or 'good' identified between inmates and employees. Namely, in both categories, approximately $80 \%$ or more respondents evaluated this innovation as 'excellent' or 'good', but there is a 
significant majority of the employees/professionals who rather see it as 'good', but not 'excellent', compared with the inmates who mostly responded with 'excellent'.

The reasons for that could be found in the fact that the inmates perceived this experience as a highly appreciated solution for their unexpected (and even dramatic) break/termination of in-person visits and therefore disregard potential negative sides of this pilot project.

Contrary, the employees, as professionals, are more aware of all the limitations of such a substitute, and see it rather as a temporary, or rather a transitional solution, either until all back to the 'old normal', or until shortcomings are identified in this transitional stage are overcome (Kolaković-Bojović and Batrićević 2021).

Additional attention should be paid to the equity in accessing the online substitutes to in-person visits. Namely, it seems that the respondents from both groups have recognized this as one of the main issues, since a number of the family members have no access to the internet, smartphones or computers, due to poverty or ICT illiteracy. This has also reiterated the need to reconsider access to this right, not only within the online environment, but in the 'old normal', too, since the same, or even bigger challenges the families from vulnerable groups face daily in their attempt to organize regular, in-person visits to their loved ones who are deprived of liberty in remote institutions. With this in mind, it seems that this pilot should be used also to explore to what extent this 'online modality' can substitute hardly affordable in-person visits, especially in situations where the distance between the place of living and the correctional institution large to the extent that the smartphone or tablet is cheaper than a travel ticket (Kolaković-Bojović and Batrićević 2021).

On the other side, within the prison community, this also brings the issue of apps to be used for this purpose, but also of the number of devices available to inmates if the prison administration decides to expand this way of communication. If accepted as an option to be implemented, procurement of additional devices, together with a widening the apps allowed to be used, can result not only in enhancing communication between the inmates and their families but also to go further, to the multipurpose use of ICT, including improvement of the e-literacy in general. Considering the growing importance of the ICT for maintaining daily-life duties and therefore widening the specter of life opportunities preconditioned by the knowledge of ICT, this should be properly recognized in the context of educational activities in correctional institutions. Gaining new knowledge and skills in this field can significantly contribute to reintegration processes, especially in terms of employment and self-employment after being released from the correctional institution. Therefore, despite the fact it has been introduced as a remedy for the extraordinary situation, this innovative approach should not be abandoned after lifting down all the restrictive measures associated with the Covid-19 pandemic. 
Contrary, this pilot project should be used by the prison administration as a fruitful ground to build upon it in a way to introduce a modern, hybrid model of approaching the right of inmates to communicate with their families.

Furthermore, it is time to consider possibilities to expand the use of ICT technologies as a part of treatment, but also in the scope of preparation for the release. This last point is of great importance in the context of enabling a better insight into the family environment of juveniles to prepare them and their family members for a new, post penal life chapter. 


\section{COMPLIANCE WITH ETHICAL STANDARDS}

Acknowledgments:

The author thanks her colleague Ms. Ana Batrićević, PhD, Senior Research Fellow in the Institute of Criminological and Sociological Research in Belgrade, who took part in collecting data analyzed in this paper.

Funding:

This paper includes findings gathered within the Impact Assessment of Re-socialisation program applied by NGO Help e.V. (Improvement of the Treatment Programs in Correctional Institutions for Adults and Juveniles - SOE03-19) funded by NGO Help e.V.

Statement of human rights:

All procedures performed in studies involving human participants were following the ethical standards of the institutional and/or national research committee and with the Declaration of Helsinki and its later amendments or comparable ethical standards.

Statement on the welfare of animals:

This article does not contain any studies with animals performed by any of the authors.

Informed consent:

Not applicable. 


\section{REFERENCES}

1. ACPH. 2020. Technical Note: Covid-19 and Children Deprived of their Liberty. The Alliance for Child Protection in Humanitarian Action.

2. Bachelet, Michelle. 2020. Urgent action needed to prevent Covid-19 "rampaging through places of detention" - Bachelet. March 25. Accessed August 18, 2021. https://www.ohchr.org/EN/NewsEvents/Pages/DisplayNews.aspx?NewsID=25745 \&Langl $=\mathrm{E}$

3. Barnert, Elizabeth. 2020. "Covid-19 and Youth Impacted by Juvenile and Adult Criminal Justice Systems." Pediatric Perspectives 146 (2). DOI: https://doi.org/10.1542/peds.2020-1299

4. Bateman, Tim. 2020. "Unjust pains: the impact of Covid-19 on children in prison." Journal of Children's Services, 201-208.

5. Halton, Lucy. 2020. Covid-19 and the Rights of Children of Parents who are incarcerated: Impacts and Recommendations. Child Rights Connect Working Group on Children of Incarcerated Parents.

6. HLPR. 2020. Children in prison during the Covid-19 pandemic A briefing from the Howard League for Penal Reform. London: Howard League for Penal Reform. Accessed August 10, 2021.

7. Kolaković-Bojović, and Ana Batrićević. 2020. Impact Assessment of Resocialisation program applied by NGO Help e.V. (Improvement of the treatment programmes in correctional institutions for adults and juveniles - SOE03-19). Belgrade: Institute of Criminological and Sociological Research.

8. Kolaković-Bojović, Milica, and Ana Batrićević. 2021. "Children in Correctional Institutions and the Right to Communicate with their Families during the Covid19 Pandemic." Teme (4).

9. Minson, Shona. 2021. "The impact of Covid-19 prison lockdowns on children." Oxford.

10. Nowak, Manfred. 2019. The United Nations Global Study on Children Deprived of Liberty. Geneva: Office of the UN High Commissioner for Human Rights.

11. UN. 1989. "Convention on the Rights of the Child Adopted and opened for signature, ratification, and accession by General Assembly entry into force 2 September 1990, in accordance with Article 49."

12. UN. 2015. "United Nations Standard Minimum Rules for the Treatment of Prisoners (the Nelson Mandela Rules) adopted by the UN General Assembly Resolution adopted by the General Assembly on 17 December 2015." 